\title{
MIND ADVANCING MOZARD; TERAPI PENINGKATAN KETERAMPILAN AFEKTIF, KOGNITIF, DAN PSIKOMOTORIK ANAK AUTIS
}

\author{
Naning Anggraini Putri \\ (Universitas Muhammadiyah Jember, Fakultas Ilmu Kesehatan, Program Studi S1 \\ Ilmu Keperawatan, Email : naninganggraini24@gmail.com) \\ Nabila \\ (Universitas Muhammadiyah Jember, Fakultas Ilmu Kesehatan, Program Studi S1 \\ Ilmu Keperawatan, Email : batarfinabila@gmail.com ) \\ Siska Helmiati Nur \\ (Universitas Muhammadiyah Jember, Fakultas Psikologi, Program Studi S1 Psikologi \\ Email : Siska.h.n99@gmail.com) \\ Yeni Suryaningsih \\ (Dosen Fakultas Ilmu Kesehatan Universitas Muhammadiyah Jember \\ Email : Yeni@unmuhjember.ac.id)
}

\begin{abstract}
ABSTRAK
Autis merupakan kondisi seseorang yang didapatkan sejak lahir yang membuat dirinya tidak mampu berhubungan sosial atau komunikasi secara normal (Smart \& Rose, 2010). Penelitian ini bertujuan untuk mengetahui tingkat keefektifan dari musik mozard terhadap peningkatan aspek afektif, kognitif, dan psikomotorik pada anak autis usia 6-12 tahun di SLB-B Bintoro Kabupaten Jember. Metode penelitian menggunakan metode quast eksperimen dengan instrumen penelitian menggunakan quisioneer dan form evaluasi. Hasil penelitian menunjukkan $\mathrm{P}<0,05$ maka berarti $\mathrm{H} 1$ diterima yang artinya ada hubungan antara terapi musik mozard terhadap kemampuan pada aspek afektif, kognitif, dan psikomotorik anak autis di SLB-B. Kesimpulan dari hasil penelitian didapatkan bahwa terapi musik mozard baik dijadikan sebagai terapi untuk meningkatkan keterampilan afektif, kognitif, dan psikomotorik anak autis.
\end{abstract}

Kata Kunci : Autis, Musik mozard, Aspek afektif, Aspek kognitif, Aspek psikomotorik

\section{ABSTRACT}

Autism is a condition of a person who is acquired from birth which makes him unable to interact socially or communicate normally (Smart \& Rose, 2010). This study aims to determine the effectiveness of Mozard's music on improving affective, cognitive, and psychomotor aspects in autistic children aged 6-12 years in SLB-B Bintoro, Jember Regency. The research method used the quast experiment method with research instruments using quisioner and evaluation forms. The results showed $P$ $<0.05$, meaning $H 1$ was accepted, which means that there is a relationship between 
Mozard's music therapy to the abilities of the affective, cognitive, and psychomotor aspects of autistic children in SLB-B. Conclusions from the results of the study found that Mozard's music therapy was used as a therapy to improve the affective, cognitive, and psychomotor skills of autistic children.

\section{Keyword : Autism, Music mozard, Affective aspects, Cognitive aspects, Psychomotor aspects.}

\section{PENDAHULUAN}

Autisme merupakan sebuah istilah yang sudah cukup merebak di kehidupan masyarakat. Istilah autisme digunakan untuk menggambarkan seorang anak yang memiliki suatu kendala dalam sistem perkembangan nya. Gangguan tersebut dapat dimulai dan dialami seorang anak pada masa kanak-kanak bahkan juga dapat timbul ketika anak masih bayi, hanya saja terkadang orang terdekat bahkan orang tua sering kali terlambat mengetahui gejala-gejala yang timbul pada anak. Hasil penulusuran yang dilakukan oleh penulis ke beberapa tempat pendidikan, didapatkan SLB-B dan Autis TPA Jember merupakan tempat pendidikan dengan jumlah anak autisme terbanyak yaitu 34 orang. SLB-B dan Autis TPA Jember yaitu salah satu sekolah berkebutuhan khusus, diantaranya autisme. Terapi musik Mozart sendiri merupakan penggunaan musik sebagai peralatan terapi untuk memperbaiki, memelihara, mengembangkan mental, fisik, kesehatan, emosi pada anak autis. Banyak dari hasil penelitian menunjukkan bahwa $80-90 \%$ penderita autisme merespon musik secara positif sebagai motivator.

Penelitian terdahulu telah dilakukan terapi yang sama terhadap anak autis namun pada penelitian terdahulu terapi musik di berikan pada anak autis hanya untuk melihat pengaruh ketrampilan motorik anak autis. Peneliti terdahulu juga menggunakan musik klasik mozard pada anak autis yang dilakukan oleh (Wahyuningrum, 2017) dengan metode penelitian menggunakan rancangan Pra Eksperimental One Group Pre Post Test Design. Sampel yang diambil adalah anak autis usia 56 tahun di Klinik Terapi Wicara Fastabikul Khoirot Bedali Lawang yang memenuhi kriteria diagnosis dalam DSM-IV. Pengambilan sampel menggunakan tehnik total sampling $(\mathrm{n}=8)$ berdasarkan kriteria inklusi yaitu usia anak autis 5-6 tahun, belum pernah dilakukan treatmen terapi musik. Penelitian dilaksanakan di Klinik Terapi Wicara Fastabikul Khoirot Bedali Lawang. Penelitian tersebut dapat diketahui bahwa terapi musik Mozart dapat meningkatkan potensi kreativitas pada anak autis usia 5-6 tahun di Klinik Terapi Wicara Bedali Lawang.

Dengan adanya penelitian ini diharapkan dapat meningkatkan perkembangan dari aspek afektif, kognitif, dan psikomotorik dari seorang anak penyandang autisme. Musik sebagai media pengembangan aspek aspek afektif, kognitif, dan psikomotorik seorang anak autis ini karena dari musik kita dapat memasuki 
fikiran dan karakter seseorang tanpa di sengaja ketika kita menghayati sebuah musik. Musik yang bersifat universal juga dapat mengolah emosi atau perasaan karena pikiran merupakan sumber dari timbulnya emosi seseorang, maka team berusaha mengolah perasaan seorang anak autis dengan media musik.

Tujuan dari penelitian ini yaitu menganalisis pengaruh musik terhadap peningkatan kemampuan bersosialisasi dan berperilaku anak autis usia sekolah (6-12 tahun) di SLBB \& Autis TPA Kabupaten Jember. Penelitian ini diharapkan dapat di aplikasikan dalam keseharian anak autis ketika sedang beristirahat, karena terapi musik mozard diharapkan mampu menjadi sebuah alternatif untuk terapi peningkatan aspek afektif, aspek kognitif, dan aspek psikomotorik pada anak.

\section{METODE PENELITIAN}

Penelitian ini menggunakan metode penelitian deskripsi analitik adalah suatu pemilihan penyajian data dalam bentuk tabel dan grafik. Ada beberapa tahap yang digunakan dalam melakukan penelitian ini diantaanya, menyusun rencana penelitian dengan mengajukan proposal penelitian yang telah di usulkan oleh ketua pengusul dan telah melalui pendampingan dengan dosen pendamping. Penelitian terapi musik mozard dilakukan di SLB-B \& TPA Autis Bintoro, Kabupaten Jember. Alat dan bahan yang digunakan dalam peneitian ini menggunakan spekers, compact disk (CD), alat tulis, lembar identitas, lembar evaluasi, buku mewarnai, krayon, dan ruang kelas SLB-B \& Autis TPA Kabupaten Jember.

Metode penelitian ini diawali dengan pengumpulan data. Informasi awal yang sudah didapatkan kemudian dicari akar permasalahannya lalu di jabarkan dalam bentuk teori dengan mendapatkan dukungan dari info kepustakaan terkait yang bersifat relevan. Penelitian ini menggunakanan metode quast eksperimen yang dilaksanakan di sekolah luar biasa (SLB)- \& Autis TPA dengan populasi penelitian ini anak autis dengan Usia 6-12 tahun. Teknik pengambilan sampel yang digunakan yaitu metode kuantitaif, instrumen atau alat ukur yang digunakan dalam penelitian ini adalah quisioner dan form evaluasi.

Analisa data yang digunakan adalah analisa univariat digunakan untuk melihat perbedaan nilai sebelum dan sesudah dilakukan perlakuan pada ketiga kelompok dan melihat selisihnya secara deskriptif. Analisis data menggunakan uji Mann-Whitney pada aplikasi SPSS 21 for Windows yang di gunakan peneliti untuk menguji apakah ada perbedaan setelah di lakukan terapi musik dan sebelum dilakukan terapi musik tersebut. Setelah melalui anaalisis data di dapatkan hasil penelitian yaitu $0,001<$ 0,05 Jadi H0 ditolak. Penelitian menunjukkan $\mathrm{P}<0,05$ maka berarti H1

diterima yang artinya ada hubungan antara terapi musik mozard terhadap kemampuan pada aspek afektif, kognitif, dan psikomotorik anak autis di SLB-B. 


\section{HASIL PENELITIAN}

Hasil penelitian menunjukkan $\mathrm{P}<0,05$ maka berarti $\mathrm{H} 1$ diterima yang artinya ada hubungan antara terapi musik mozard terhadap kemampuan pada aspek afektif, kognitif, dan psikomotorik anak autis di SLB-B melalui Uji Mann-Whitney. Sebagian besar responden memiliki umur 6-10 tahun dengan jumlah 12 responden $(60 \%)$ dan umur $>10$ tahun tahun dengan jumlah 8 responden (40 $\%)$. Pada hasil analisis menunjukan bahwa sebagian besar responden berjenis kelamin perempuan dengan jumlah 16 responden $(80 \%)$ dan lakilaki dengan jumlah 4 responden (20\%). Dari hasil penelitian didapatkan perubahan aspek afektif, kognitif, dan psikomotrik anak autis yang cukup signifikan. Pada aspek afektif didapatkan perubahan antara sebelum dan sesudah dilakukan terapi musik mozard yaitu 9 responden dari 12 responden kelompok perlakuan (75
$\%)$, sedangkan pada kelompok kontrol peningkatan tersebut tidak sebesar pada kelompok perlakuan yaitu 4 responden dari 8 responden kelompok kontrol $(50 \%)$. Pada aspek kognitif didapatkan hasil perubahan antara sebelum dan sesudah dilakukan terapi musik mozard yaitu 8 responden dari 12 responden kelompok perlakuan $(66,6 \%)$, sedangkan pada kelompok kontrol peningkatan tersebut tidak sebesar pada kelompok perlakuan yaitu 2 responden dari 8 responden kelompok kontrol (25\%). Pada aspek psikomotorik didapatkan perubahan antara sebelum dan sesudah dilakukan terapi musik mozard yaitu 9 responden dari 12 responden perilaku perlakuan (75\%), sedangkan pada kelompok kontrol peningkatan tersebut tidak sebesar pada perilaku perlakuan yaitu 4 responden dari 8 responden kelompok bebas $(50 \%)$.

Tabel 1. Hasil Uji Mann Withney

\begin{tabular}{|c|c|c|c|c|c|}
\hline \multicolumn{5}{|c|}{ Ranks } & \multirow{6}{*}{$\begin{array}{ll}\text { a. } & \text { sesudah }<\text { sebelum } \\
\text { b. } & \text { sesudah }>\text { sebelum } \\
\text { c. } & \text { sesudah }=\text { sebelum }\end{array}$} \\
\hline \multirow{5}{*}{$\begin{array}{l}\text { sesudah } \\
\text { sebelum }\end{array}$} & & $\mathrm{N}$ & Mean Rank & Sum of Ranks & \\
\hline & $\begin{array}{l}\text { Negative } \\
\text { Ranks }\end{array}$ & $4^{\mathrm{a}}$ & 2,63 & 10,50 & \\
\hline & $\begin{array}{l}\text { Positive } \\
\text { Ranks }\end{array}$ & $15^{\mathrm{b}}$ & 11,97 & 179,50 & \\
\hline & Ties & $1^{c}$ & & & \\
\hline & Total & 20 & & & \\
\hline
\end{tabular}


Tabel 2. Karakteristik Responden Berdasarkan Usia Pada Anak Autis di SLB-B \& TPA Autis Jember

\begin{tabular}{cccc}
\hline No & Usia & Frekuensi & $\%$ \\
\hline 1 & 6-10 tahun & 12 & $60 \%$ \\
2 & $>10$ tahun & 8 & $40 \%$ \\
\hline Total & & 20 & $100 \%$ \\
\hline
\end{tabular}

Tabel 3. Karakteristik Responden Berdasarkan Jenis Kelamin Pada Anak Autis di SLB-B \& TPA Autis Jember

\begin{tabular}{|c|c|c|c|}
\hline No & Jenis Kelamin & Frekuensi & $\%$ \\
\hline 1 & Laki-laki & 4 & $20 \%$ \\
\hline 2 & Perempuan & 16 & $80 \%$ \\
\hline Total & & 20 & $100 \%$ \\
\hline
\end{tabular}

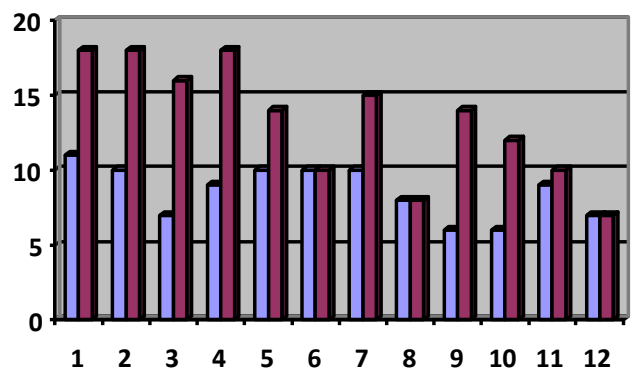

Pretest Kelompok Perlakuan

Postest Kelompok Perlakuan

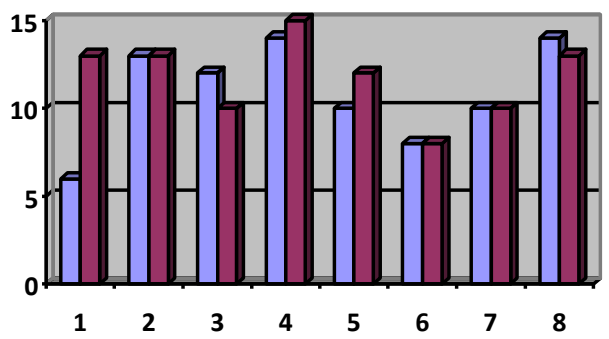

Pretest Kelompok Kontrol

$\square$ Postest Kelompok Kontrol

Grafik 1. Pengaruh Musik Mozard Terhadap Aspek Afektif Anak Autis di SLB-B \& TPA Autis Jember 

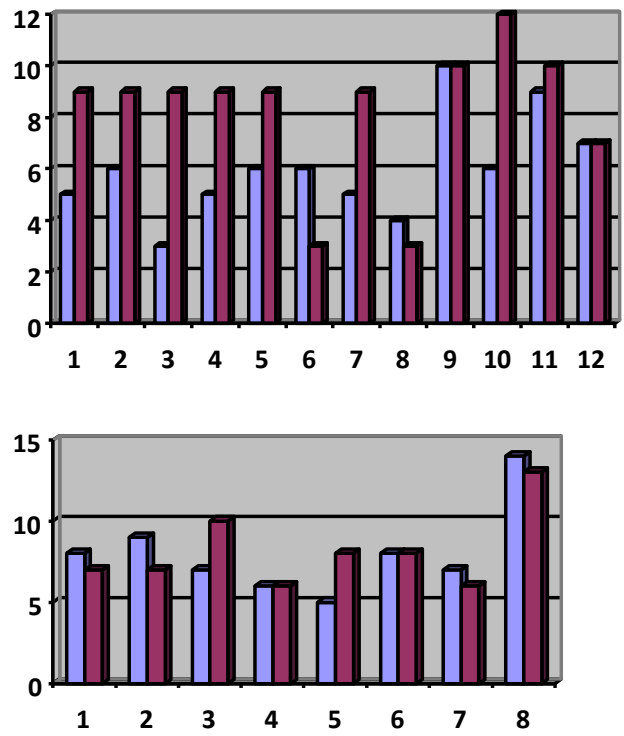

Pretest Kelompok Perlakuan

$\square$ Postest Kelompok Perlakuan
Pretest Kelompok Kontrol

$\square$ Postest Kelompok Kontrol

Grafik 2. Pengaruh Musik Mozard Terhadap Aspek Kognitif Anak Autis di SLBB \& TPA Autis Jember

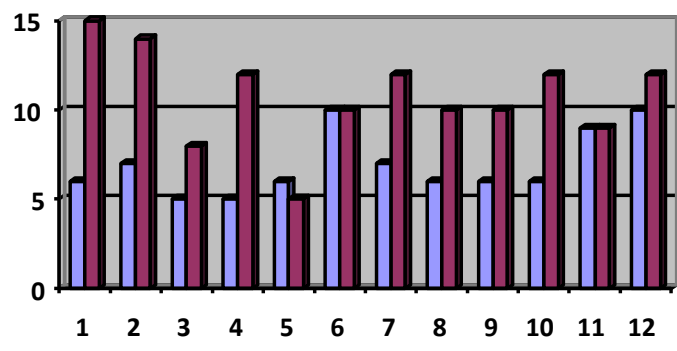

\author{
Pretest Kelompok Perlakuan \\ Postest Kelompok Perlakuan
}

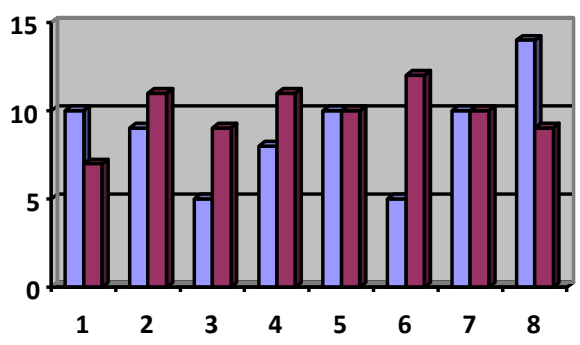

Pretest Kelompok Kontrol

口 Postest Kelompok Kontrol

Grafik 3. Pengaruh Musik Mozard Terhadap Aspek Psikomotorik Anak Autis di SLB-B \& TPA Autis Jember

\section{PEMBAHASAN}

Berdasarkan penelitian yang telah dilakukan terdapat perubahan disetiap aspek peningkatan aspek afektif anak autis dapat dicapai melalui kegiatan diantaranya, memutarkan musik mozard selama pembelajaran dalam waktu 1 jam. Hal ini sesuai dengan efek musik mozard yang dapat memberikan kenyamanan bagi anak autis karena alunan musik mozard memiliki frekuensi nada rendah dan tinggi 
untuk mempengaruhi kuadran c pada sel otak. Kuadran c yang bersifat visual (feeling).

Musik berhasil merangsang suatu pola dan jembatan pemikiran yang lebih kompleks. Didukung oleh penelitian yang dilakukan oleh Martin Gardiner (1996) dalam Goleman (1995) mengatakan bahwa seni dan musik dapat membuat anak pintar dan membantu otak berfokus pada hal yang dipeajari. Peningkatan aspek kognitif anak autis dapat dicapai melalui beberapa kegiatan, yaitu memberikan bentuk gambar yang berisikan angka dan huruf untuk disebutkan ulang. Suatu kegiatan menyebutkan ulang angka dan huruf yang sudah di ajarkan melatih untuk meningkatkan daya ingat anak autis.

Keterampilan motorik halus membutuhkan suatu koordinasi mata dan tangan serta koordinasi gerak dan daya konsentrasi. Keterampilan motorik dapat dikembangkan dengan kegiatan diantaranya dengan menggambar, mewarnai, dan meyisipkan hingga bermain puzzle. Sejalan dengan teori Rahyubi (2012) menjelaskan bahwa untuk latihan yang terpola dan teratur mampu membuat seseorang menjadi terampil dan tangkas. Memberikan berbagai warna yang berbeda kepada anak autis. Pemberian berbagai warna pada anak autis berfungsi untuk melatih konsentrasi dan meningkatkan daya kreativitas anak autis. Peningkatan aspek psikomotorik anak autis dapat dicapai melalui beberapa kegiatan diantaranya, yaitu:

a. Mewarnai. Kegiatan mewarnai untuk melatih meningkatkan kemampuan reaksi dan persepsi yang baik pada anak autis b. Bermain badminton. Kegiatan ini bertujuan untuk meningkatkan kemampuan mobilitas (gerak) yang baik dan meningkatkan motorik kasar dan halus bagi anak autis.

\section{SIMPULAN}

Berdasarkan hasil penelitian dan pembahasan, secara keseluruhan tentang pelaksanaan terapi musik Mind Advancing Mozard bagi anak autis khususnya di SLB-b \& TPA Autis Bintoro, Kabupaten jember dapat dibuktikan bahwa terapi musik mozard baik dijadikan sebagai terapi untuk meningkatkan keterampilan afektif, kognitif, dan psikomotorik anak autis.

\section{SARAN}

\section{Bagi Sekolah}

Diharapkan dari hasil penelitian ini dapat dipergunakan sebagai dasar perencanaan dalam pelaksanaan keterampilan dalam aspek kognitif, afektif, dan psikomotorik yang lebih baik bagi siswa autis.

2. Bagi Guru

Guru lebih bervariasi dalam penggunaan alat terapi musik di setiap pelaksanaan pembelajaran agar dalam penyampaian materi dapat lebih mudah untuk diserap dan dipahami oleh siswa autis.

3. Bagi Peneliti Selanjutnya

Dari hasil penelitian ini data dapat bermanfaat yakni digunakan sebagai kelanjutan bagi peneliti yang akan datang untuk melakukan penelitian lebih lanjut dengan memperhatikan keterbatasan dari penelitian sebelumnya dengan harapan hasil 
yang didapat lebih baik dari peneliti sebelumnya.

\section{UCAPAN TERIMA KASIH}

Kami mengucapkan terima kasih kepada Direktorat Jendral Pendidikan Tinggi, Kementrian Pendidikan Nasional atas bantuan dana pengabdian kepada masyarakat ini. Terima kasih juga kami sampaikan kepada Kepala Sekolah SLB-B \& Autis Kabupaten Jember dan segenap jajaran guru SLB-B \& Autis yang banyak mendukung kegiatan ini.

\section{DAFTAR PUSTAKA}

Ahmadi, A. 2003. Psikologi Umum. Jakarta: PT.Rineka Cipta.

Delphie, Bandi. 2009. Pendidikan Anak Autis. Sleman: PT Intan Sejati Klaten.

Djohan. 2009.Psikologi Musik. Yogyakarta: Best Publisher
Goleman, Daniel. 1995. Emotional Intelligence. Jakarta. PT. Gramedia Pustaka Utama.

Keliat, Budi A, dkk. 2014. Scanning Pengkajian Keperawatan Jiwa Lanjut. Depok: Universitas Indonesia

Maulana, Mirza. 2008. Anak Autis. Jogjakarta: Kata Hati

Rahyubi, Heri. 2012. Teori-teori Belajar dan Aplikasi Pembelajatan Motorik: Deskrisi dan Tinjauan Kritis. Jawa Barat. Referens

Safira,Triantoro. 2005. Autisme Pemahaman Untuk Hidup Bermakna Bagi Orang Tua. Yogyakarta: Graha Ilmu.

Wahyuningrum, Damayanti Ari. 2017. Pengaruh Terapi Musik Terhadap Perubahan Potensi Kreativitas Anak Autis. Malang: Jurnal Ilmu Keperawatan. 